\title{
Life Cycle Assessment of Sajor-caju Mushroom (Pleurotus Sajor-caju) from Different Sizes of Farms in Thailand
}

\author{
S. Ueawiwatsakul, T. Mungcharoen, and R. Tongpool
}

\begin{abstract}
Sajor-caju (Pleurotus sajor-caju) is one of the most famous mushroom in Thailand. Sajor-caju farming uses plastic bags for cultivation. Energy is needed for sterilization of substrate and waste management of spent plastic bag. Thailand has several sizes of sajor-caju farms which have different cultivation management. Therefore, the environmental performance of sajor-caju produced from three farm sizes was evaluated in this study using life cycle assessment approach. It was found that the main impacts came from i) substrate preparation which are the production and transportation of the substrate raw materials and ii) sterilization process. Medium farm showed relatively large impacts in all impact categories. The climate change caused by $1 \mathrm{~kg}$ sajor-caju produced from big, medium and small farms were $3.371,5.003$ and $3.0146 \mathrm{~kg}$ $\mathrm{CO}_{2}$ eq, respectively.
\end{abstract}

Index Terms-LCA, Pleurotus sajor-caju, environment.

\section{INTRODUCTION}

Pleurotus sajor-caju is a kind of oyster mushrooms, known as "Hed Nangpha" in Thailand. It is one of the popular edible mushrooms and is commercially cultivated in Thailand. The substrate for Pleurotus sajor caju is based on sawdust, rice straw that are agricultural by-products [1]. Sajor-caju high content of protein and low content of fat. It also contains vitamins (B1, B2, C, A), minerals (P, Na, Ca) and high content of fibers and carbohydrates [2].

There are many products from sajor-caju such as fried Sajor-caju, soup, chilli sauces. The environmental performance of saju-caju will influence environmental performance of food having sajor-caju as ingredients. Sajor-caju is mainly grown in the middle of Thailand [3]. However, some of raw materials such as sawdust have to be transported from the southern part of the country.

Cultivation of sajor-caju in plastic bag has certain environmental issues. Energy is needed for sterilization of substrate and waste management of spent plastic bag is required. In Thailand, there are several sizes of sajor-caju farms which have different cultivation management such as waste management, energy consumption, water consumption [3]. This work divided the farms into three sizes, big, medium

Manuscript received November 12, 2013; revised February 12, 2014 This work was supported in National Science and Technology Development Agency (NSTDA)

S. Ueawiwatsakul is with Thailand Advanced Institute of science and Technology and Tokyo Institute of Technology (TAIST-Tokyo Tech), Faculty of Engineering, Kesetsart University, Bangkok 10900, Thailand (e-mail: a_uknow8@hotmail.com).

T. Mungcharoen is with the Faculty of Engineering, Kasetsart University, Bangkok 10900, Thailand (e-mail: thumrongrut@nstda.or.th).

R. Tongpool is with the National Metal and Materials Technology Center, Pathumthani, 12120, Thailand (e-mail: rungapt@mtec.or.th). and small.

As life cycle assessment (LCA) method was reported to be able to identify environmental impacts [4]. It was used to study how to improve environmental performance of sajor-caju produced from the three sizes of farms.

\section{MATERIALS AND METHODS}

\section{A. Goal}

This study aims to evaluate the potential environmental impacts of sajor-caju produced from three different sizes of farms in Thailand, The hotspots of life cycle of sajor-caju were identified. This is to find out possible means for environmental performance improvement of the sajor-caju.

\section{B. The System and Scope}

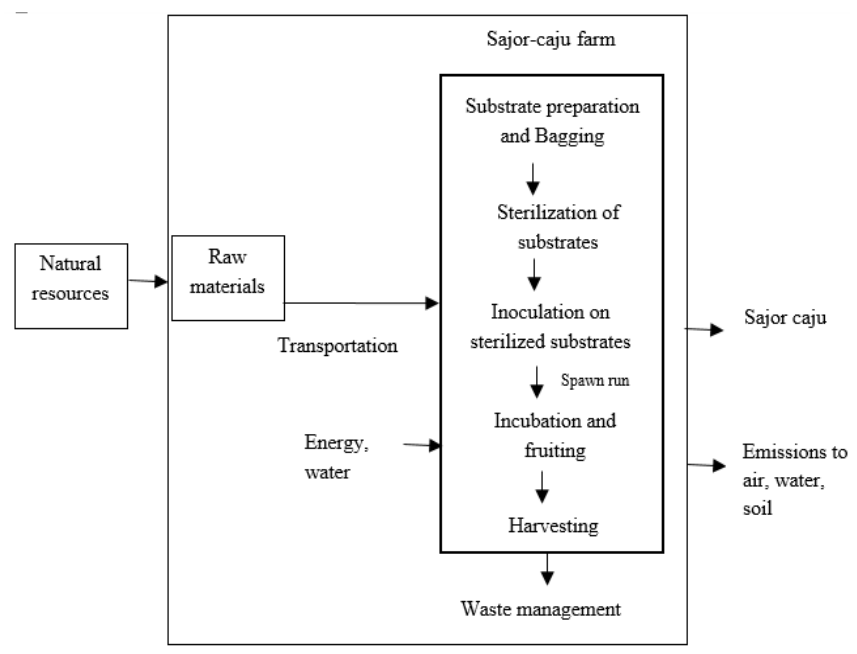

Fig. 1. Boundary system of sajor-caju product under LCA approach.

The study includes raw material acquisition, cultivation, and waste management (Cradle to Gate approach) as shown in Fig. 1. The cultivation process consists of substrate preparation, sterilization, inoculation, incubation, fruiting and harvesting. First the plastic bag was filled with substrate mixture. Trucks were used to carry the substrate materials and the other inputs to the farms. Second, a plastic ring was applied at the top of bag. A cotton ball or paper was plugged in the hole on the top of the bag and rubber band was applied. Third, sterilization of substrate was carried out using a steam for 3-4 hr. A firewood and liquefied petroleum gas (LPG) were used as fuel for steam generation. When it was cooled in room temperature, the spawn was put inside the bag and then the spawn runs for 28-30 days. After that it was incubated for 3-4 months. After fruiting, it is ready for harvest. After harvest, spent paper, spent plastic, spent cotton fabric and 
spent rubber band which were expired were burnt out or thrown away as garbage. The substrates and residues of sajor-caju were sold out to produce fertilizer.

The functional unit is $1 \mathrm{~kg}$ of sajor-caju produced from the house farm. LCI data were collected from thirty one farms by interviewing with farmers in Ratchaburi province, where $30.88 \%$ of total sajor-caju of the country was produced [3]. The data of the input and output of sajor-caju production is shown in Table I. The amounts of $\mathrm{CH}_{4}$ and $\mathrm{N}_{2} \mathrm{O}$ from firewood, gasoline, and LPG combustion for steam generation were obtained by calculation using the emission factors from IPCC 2006 [5]. The amount of $\mathrm{CO}_{2}$ from firewood combustion was not included in inventory because wood absorbs $\mathrm{CO}_{2}$ from atmosphere during growing stage. Emissions of $\mathrm{CO}, \mathrm{SO}_{2}, \mathrm{NO} x$, NMVOC, PM10 and PM2.5 of firewood, gasoline and LPG combustion were calculated using emission factors from EMEP/EEA air pollutant emission inventory guidebook 2013 [6]. The open burning of spent paper, spent plastic, spent cotton fabric and spent rubber band, causes emissions to air. The amounts of $\mathrm{CO}_{2}$, $\mathrm{N}_{2} \mathrm{O}$ and $\mathrm{CH}_{4}$ were obtained by calculation using the emission factors from IPCC 2006 [5]. The amounts of, NOx, VOC, $\mathrm{CO}, \mathrm{SO}_{2}, \mathrm{PM} 10, \mathrm{PM} 2.5$ were calculated using emission factors from EPA [7]. The impacts from buildings and machinery were excluded in this study.

This work divided the farms into three groups according to the amount of cubes of all types of mushroom cultivated in the farm. The amounts of overall mushroom produced per year for small, medium and big farm sizes are shown in Table II. This criteria was suggested by Ratchaburi Agriculture office, Thailand. There are fifteen farms in the big size group and eight farms in each small and medium size groups.

TABLE I: THE DATA OF INPUT AND OUTPUT OF SAJOR-CAJU PRODUCTION

\begin{tabular}{ll}
\hline \hline Process & Input \\
\hline & Sawdust, Rice bran, Water, Urea fertilizer, Magnesium sulphate, Lime, \\
Substrate preparation & Gypsum, Rice flour, Cassava flour, Glutinous rice flour, Pumice, Cotton, \\
& Rubber band, Plastic bag, Molasses, Paper, Neck ring, Human labour, \\
& Electricity, Transportation of inputs
\end{tabular}

Firewood, Liquefied petroleum gas (LPG), Transport of firewood and LPG, Water, Human labour

Spawn, Transportation of spawn, Human labour

Water, Electricity, Gasoline, pesticide, Transport of gasoline and pesticide, Human labour

Plastic bag, Transportation of plastic bag, Human labour

Spent substrate, Spent bag, Spent neck ring, Spent paper, Spent cotton fabric, Spent rubber band, residue of sajor-caju
$\mathrm{CO}_{2}, \mathrm{CH}_{4}, \mathrm{~N}_{2} \mathrm{O}$, NOx, CO, NMVOC,

$\mathrm{SO}_{2}$, TSP, PM10, PM2.5

Cube mushroom

Water, $\mathrm{CO}_{2}, \mathrm{CH}_{4}, \mathrm{~N}_{2} \mathrm{O}, \mathrm{NO} x, \mathrm{CO}$, NMVOC, $\mathrm{SO}_{2}$, TSP, PM10, PM2.5

Spent substrate, Spent bag, Spent neck ring, Spent paper, Spent cotton fabric, Spent rubber band

$\mathrm{CO}_{2}, \mathrm{CH}_{4}, \mathrm{~N}_{2} \mathrm{O}$, NOx, CO, VOC, $\mathrm{SO}_{2}, \mathrm{PM} 10, \mathrm{PM} 2.5$

\begin{tabular}{lll}
\hline \hline & TABLE II: THE DIVIDED SIZES OF FARMS \\
\hline \hline & $\begin{array}{l}\text { Cubes of all kinds of } \\
\text { mushroom (Bag per farm) }\end{array}$ & $\begin{array}{l}\text { Weight of all kinds of } \\
\text { mushroom produced per } \\
\text { year (kg per year) }\end{array}$ \\
\hline Small farm & $<40,000$ & $<20,000$ \\
Medium farm & $40,000-80,000$ & $20,000-40,000$ \\
Big farm & $>80,000$ & $>40,000$ \\
\hline \hline
\end{tabular}

The data of inputs and outputs of all farms in each group were weighted averaged according to the annual production. In 2012, the farms produced sajor-caju twice a year. The data coverage was $21.79 \%$ of overall sajor-caju in Thailand in 2012.

The data of the inputs and transportations of each group were traced back to natural resource consumption and emissions of the upstream processes. The background data of LPG, gasoline, electricity, tap water, sawdust, polypropylene, transportation were provided by Thailand national LCI database. The background data of rice bran came from the inventories of milled rice production [8]. The background data of plant hormone for incubation and fruiting was excluded from the study because it could not be found. The other background data were obtained from Ecoinvent database in SimaPro software.

\section{Environmental Impact Assessment}

After LCI was obtained, the classification and characterization method of ReCiPe Midpoint was applied via SimaPro 7.3.3 software [9]. The concerned impact categories in this study are 1) climate change, expressed as $\mathrm{kg} \mathrm{CO}_{2}$ equivalent, 2) marine eutrophication, expressed as $\mathrm{kg} \mathrm{N}$ equivalent, 3) human toxicity, expressed as $\mathrm{kg}$ 1,4-DB equivalent, 4) water depletion, expressed as $\mathrm{m}^{3}, 5$ ) fossil depletion, expressed as $\mathrm{kg}$ oil equivalent.

\section{RESULTS}

\section{A. Environmental Impacts from Different Farm Sizes}

The results of environmental impact assessments of sajor-caju are shown in Table III. It can be seen that the sajor-caju from the medium farms caused the highest impacts in all impact categories, especially, climate change The climate change caused by $1 \mathrm{~kg}$ sajor-caju produced from big, 
medium and small farms were $3.371,5.003$ and $3.0146 \mathrm{~kg}$ $\mathrm{CO}_{2}$ eq, respectively. The impact of sajor-caju from the big and small farms were almost the same. The impact of climate change of sajor-caju in all size farms higher than shiitake (1.8671 $\mathrm{kg} \mathrm{CO}_{2}$ eq), in the categories of human toxicity and fossil depletion were lower than shiitake $(0.0563 \mathrm{~kg} 1,4-\mathrm{DB}$ eq, $0.5851 \mathrm{~kg}$ oil eq) [10].

\section{B. Contributors of the Environmental Impacts}

The impact contributors were grouped in 6 processes; i) substrate preparation ii) sterilization, iii) inoculation, iv) incubation and fruiting, v) harvesting, and vi) waste management, as shown in Fig. 2. It can be seen that the substrate preparation, and sterilization are the main impact contributors for all farms sizes and for all impact categories. The medium farms caused the highest impacts in all categories and all impact contributors. The sterilization process was more than $70 \%$ of total impacts in the category of climate change.

TABLE III: ENVIRONMENTAL IMPACTS OF 1KG OF SAJOR-CAJU FROM THREE SIZES OF FARMS

\begin{tabular}{lllr}
\hline \hline & & & \\
Impact category & Unit & Small size & Medium size \\
\hline Climate change & & & 3.371086 \\
Marine eutrophication & $\mathrm{kg} \mathrm{CO}$ eq & 3.014518 & 5.002945 \\
Human toxicity & $\mathrm{kg} \mathrm{N} \mathrm{eq}$ & 0.005778 & 0.007604 \\
Water depletion & $\mathrm{kg}^{3} 1,4-\mathrm{DB}$ eq & 0.024677 & 0.028359 \\
Fossil depletion & $\mathrm{kg} \mathrm{oil} \mathrm{eq}$ & 0.198833 & 0.275168 \\
& & 0.116995 & 0.125464 \\
\hline \hline
\end{tabular}

The medium size of farms showed the highest impact relatively large amount of firewood was used. The replacement of firewood with $\mathrm{LPG}$ will reduce released $\mathrm{CH}_{4}$, $\mathrm{N}_{2} \mathrm{O}, \mathrm{CO}, \mathrm{NO} x, \mathrm{SO}_{2}, \mathrm{NMVOC}, \mathrm{PM} 10$ and PM2.5. However, the amount of $\mathrm{CO}_{2}$ will increase, resulting in higher impacts in the categories of climate change and fossil depletion.

The impact of Marine eutrophication mainly came from both substrate preparation and sterilization for all farm sizes. Fig. 4 shows that sawdust was the reason for the impact in the substrate preparation. Fig. 3 shows that the emission from sterilization was the reason for the impact in sterilization process.

The result of human toxicity mainly came from substrate preparation for all farm sizes. The sawdust was more than $50 \%$ of total impact as shown in Fig. 4.

The substrate preparation was the main cause of fossil depletion category for all farm sizes. This came from sawdust and transportation as shown in Fig. 4.

In Fossil water depletion category, substrate preparation showed relatively large contribution, which were $89 \%$ of big farms, $85 \%$ of medium farms and $82 \%$ of small farms. This came from rice bran as shown in Fig. 4.

Fig. 3 shows that transportation of fuels and the emissions from burning were the main causes for the impact of sterilization process. This is because firewood and LPG were used for steam generation. These results were the same for all farm sizes. The combustion of firewood released $\mathrm{CH}_{4}, \mathrm{~N}_{2} \mathrm{O}$,
$\mathrm{CO}, \mathrm{NO} x, \mathrm{SO}_{2}, \mathrm{NMVOC}, \mathrm{PM} 10$ and PM2.5 which can cause climate change and marine eutrophication and water depletion. The prevention of heat loss will reduce fuel consumption and environmental impacts.

The contributions of environmental impact from the substrate preparation process were mainly from the productions of rice bran and sawdust, as well as the transportations of the substrate raw materials as shown in Fig. 4. These results were the same for all farm sizes. The rice bran was more than $70 \%$ of the total impact in water depletion. The sawdust was more $40 \%$ of the total impacts in the categories of climate change, marine eutrophication, human toxicity and fossil depletion. More than $20 \%$ of climate change came from the transportation. The transported from the southern of Thailand which was very far from the farms which is about $500-800 \mathrm{~km}$. The environmental performance of sajor-caju can be largely improved if the sawdust sources are close to farms or replacement of sawdust with rice straw, corn and other agricultural by-products having relatively low environmental impacts might be an alternatives. It was reported that used rice straw with cottonseed in the substrate improved sajor-caju yield [11]. Since certain agricultural by products should be milled or ground before used as substrate including energy and expense is needed. Environmental performance of sajor-cajor with innovated substrate should be assessed.

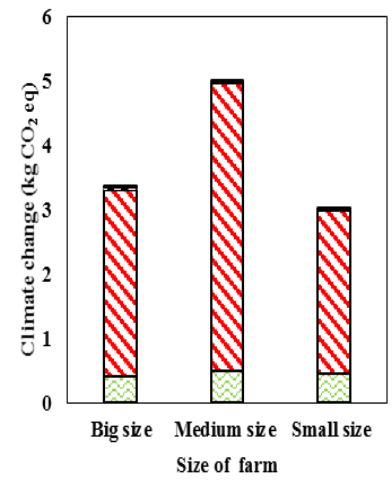

(a)

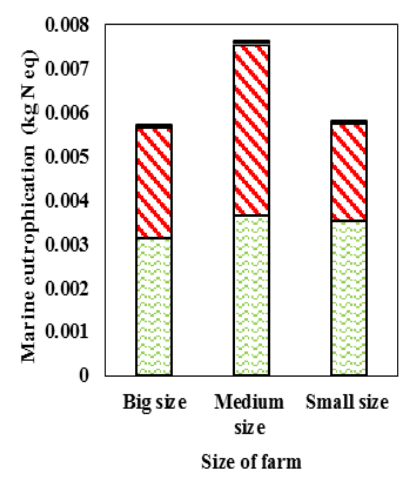

(b)
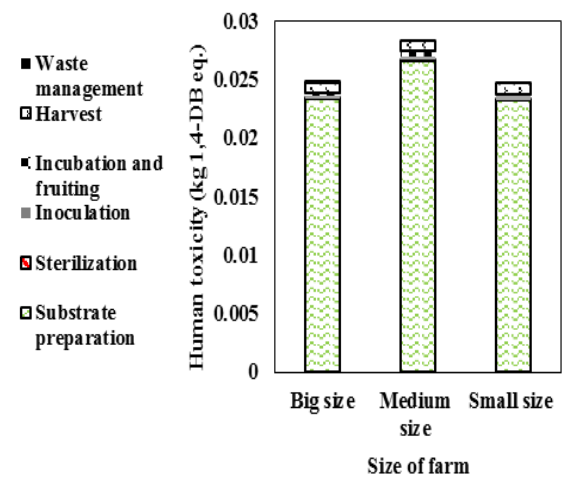

(c) 


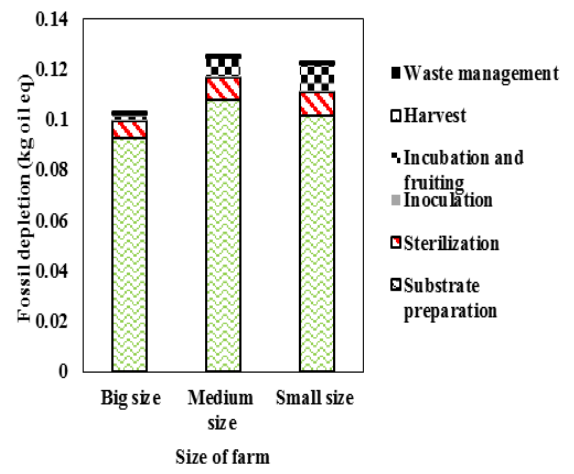

(d)

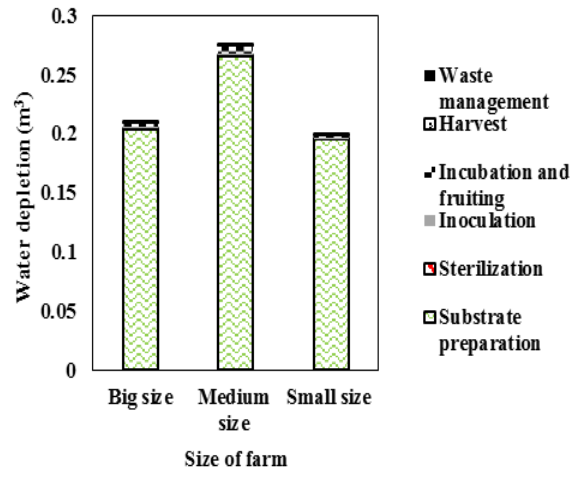

(e)

Fig. 2. Impact contributions of $1 \mathrm{~kg}$ of sajor ca-ju in the categories of (a) Climate change, (b) Marine eutrophication, (c) Human toxicity, (d) Fossil depletion and (e) Water depletion.

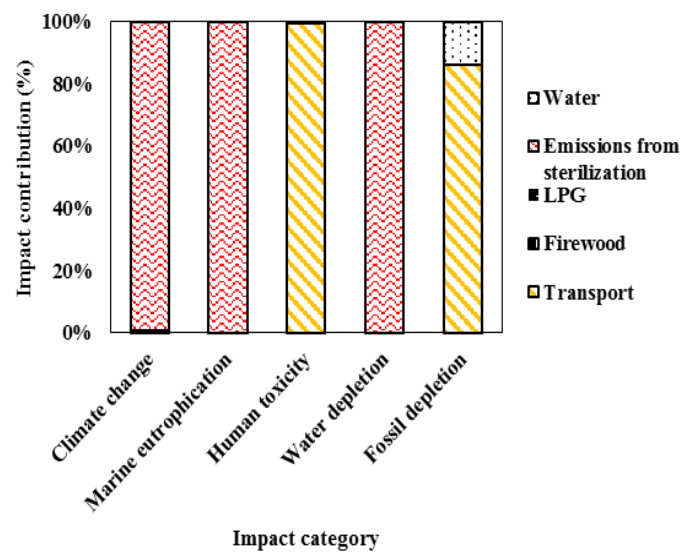

Fig. 3. Impact contribution from sterilization of the substrate that yield $1 \mathrm{~kg}$ of sajor-caju in big farms.

In the impact contributions of substrate preparation and sterilization of sajor-caju farms, the results were consistent with shiitake farms in Thailand that came from i) production of sugar and rice bran used as a substrate ii) transportation of sawdust and firewood used as a substrate and fuel iii) fuel burning during sterilization process [10]. If the sawdust was transported in distance of $100 \mathrm{~km}$ and if the spent bages and neck rings were not burnt but used for plastic recycling, the impact of fossil depletion and climate change can be reduced that were reported [10]. It is interesting for environmental performance of sajor-caju farms.

\section{CONCLUSION}

This study employed life cycle assessment (LCA) to quantify potential impacts of Pleurotus sajor-caju cultivation from different sizes of farms. The results showed that the substrate preparation and sterilization were the main impact contributors for all farm sizes in impact categories which were climate change, marine eutrophication, human toxicity, water depletion and fossil depletion. It is found that the Pleurotus sajor-caju from medium farms showed higher environmental burden than the big and small farms because large amount of the raw materials in substrate preparation and fuel in sterilization process. As the sajor-caju is largely produced in Thailand, the reduction of its impact can influence environment of the country.

\section{ACKNOWLEDGMENT}

This study was accomplished through the financial support

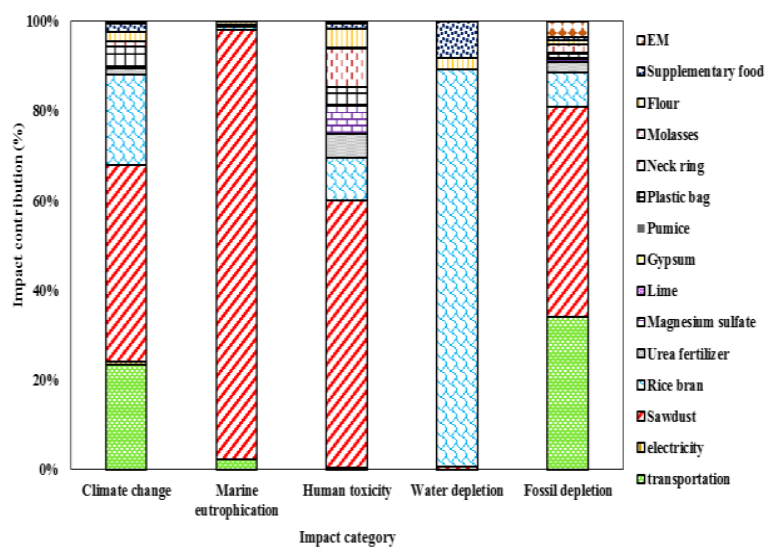

Fig. 4. Impact contributions from the substrate that yield $1 \mathrm{~kg}$ of sajor-cajuin big farms.

of National Science and Technology Development Agency (NSTDA) Thailand, under the Thailand National LCI Database Project, Thailand Advanced Institute of Science and Technology and Tokyo Institute of Technology (TAIST-Tokyo Tech), and Faculty of Engineering, Kesetsart University. We acknowledge the Department of Agriculture and Farmers in Ratchaburi province for data collection.

\section{REFERENCES}

[1] C. Wongsangprai, Bag Cultivation of Mushroom, Kasetsiam, Bangkok, 2012, ch. 1, pp. 7-9.

[2] Anonymous Sajor-caju, Laboratory Center for Food and Agricultureal Products, 2007.

[3] Anonymous Sajor-caju, Analysis and Information Systems, Department of Agricultural Extension, 2012.

[4] G. Rebitzer, T. Ekvall, R. Frischknecht et al., "Life cycle assessment: Part 1: Framework, goal and scope definition, inventory analysis, and applications," Environment International, vol. 30, no. 5, pp. 701-720, 2004.

[5] IPCC, IPCC Guidelines for National Greenhouse Gas Inventories, 2006.

[6] EMEP/EEA Air Pollutant Inventory Guidebook, 2013.

[7] U.S. Environmental Protection Agency, "Emission inventory improvement program," Open Burning, vol. 3, ch. 16, January 2001.

[8] H. Nadsathaporn, "Environmental life cycle assessment of rice products," M.eng. Thesis, Faculty of Environmental Engineering Suranaree University of Technology, Nakorn Ratchasima, Thailand, 2007.

[9] Pre Consultants, SimaPro, the Netherlands, 2013.

[10] R. Tongpool and P. Pongpat, "Analysis of shiitake environmental performance via life cycle assessment," presented at the ICGES, Hong Kong, July 6-7, 2013.

[11] M. N. Shashirekha, S. Rajaratham, and Z. Bano, "Enhancement of bioconversion efficiency and chemistry of the mushroom, Pleurotus sajor-caju (Berk and Br.) Sacc. Produced on spent rice straw substrate, supplemented with oil seed cakes," Food Chemistry, vol. 76, pp. 27-31, 2002. 


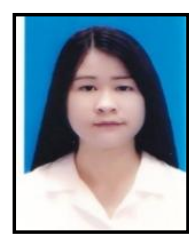

S. Ueawiwatsakul was born in Thailand. She graduated from Silpakorn University in 2012, Thailand and now she is studying master degree in advanced and sustainable environmental engineering in second year from Thailand Advanced Institute of Science and Technology and Tokyo Institute of Technology (TAIST-Tokyo Tech), Faculty of Engineering, Kesetsart University.

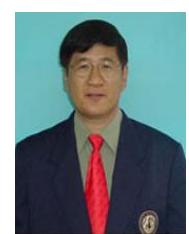

T. Mungcharoen was born in Thailand. He graduated from Chulalongkorn University, Thailand and got master and $\mathrm{PhD}$ degree in chemical engineeing from University of Texas (Aistin), USA

$\mathrm{He}$ is currently a director in Cleaner Technology Eco-design Research Unit, Kasetsart University. He is also the director of Sustainable Environment Program and chairman of Energy and Environment Cluster National Science and Technology Development Agency (NSTDA). His Research area is in cleaner technology, life cycle assessment, eco-design, process safety and risk analysis. He is among the key persons who have started the Thai Life Cycle Inventory Database project and the Thai Carbon Footprint project. He sits in an executive board of the Asia Pacific Roundtable on Sustainable Consumption and Production. He has more than 180 scientific publications.

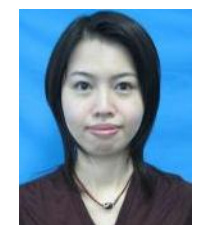

R. Tongpool was born in Thailand. She graduated from Kesetsart University, Thailand and got her master and $\mathrm{PhD}$ degree in materials science in 2000 from University of Manchester Institute of Science and Technology (UMIST), Manchester, UK.

Her started career as a researcher at National Metal and Materials Technology Center (MTEC), Thailand in 2000. In the first seven years, her work had focused on materials research, such as gas sensing materials, photocatalyst, dye sensitized solar cell, UV and IR preventive film. The she joined life cycle assessment (LCA) laboratory at MTEC, carrying on national life cycle inventory (LCI) establishment. The national LCI has been applied in carbon footprint calculation and environmental assessment of commercial products. She is one of the committee, setting up national carbon footprint scheme. Now she holds the position as LCA lab head and principal researcher. She also gives consultancy to private companies on carbon footprint, LCA for product development. 